\title{
'Transnational Identities of the Global South Asian Diaspora in Australia, Canada, Aotearoa New Zealand, and South Africa, 1900s- 1940s'
}

\section{Jatinder Mann ${ }^{1}$}

This article will address two key research questions: 1 . Was the rhetoric about the equality of all British subjects adopted by South Asian² migrants in the British

Empire's self-governing Dominions in the first half of the twentieth century? and 2.

Did the experience of living in predominantly white countries encourage migrants from the Punjab and other regions in South Asia to adopt a common pan-South Asian identity? I will explore these two research questions within Australia, Canada, Aotearoa New Zealand, and South Africa, before making some comparisons. Due to Covid-19 the primary research for this article was limited to the British Library and National Archives of the United Kingdom (UK). As such this article presents an initial overview and the findings of the research may be further developed once the pandemic allows and other archives can be consulted. Furthermore, I have had to draw on the existing secondary literature much more for the Aotearoa New Zealand case study as there was not much primary material available in the archive that I consulted. This is probably a reflection of the fact that the South Asian community in Aotearoa New Zealand was very small during the time period covered by this article and consequently was not given much attention by the British imperial authorities, especially compared to the much larger communities in South Africa and Canada.

\footnotetext{
1 I would like to thank Dr. Ali Clark for managing the submission process of this article, from arranging its peer review to making an editorial decision on whether to publish it in the journal, as well as the two anonymous reviewers for their comments and suggestions. I would also like to acknowledge the financial support of the Research Grants Council of Hong Kong, specifically an Early Career Scheme Grant (22600319), which allowed me to carry out the research on which this article is based.

${ }^{2}$ My article intentionally uses the term 'South Asian' rather than 'Indian', although I am of course aware that during the period that this article covers there was no Pakistan, Sri Lanka, or Bangladesh in existence, but just British India. However, I find the term 'South Asia' more inclusive and reflective of the fact that many 'Indian' migrants came from what is now Pakistan. I will of course use terms that were used at the time in any direct quotes from historical sources.
} 
Putting the first research question in a broader historical context it relates to Queen Victoria's proclamation of 1858. According to Sukanya Banerjee:

Upon the termination of the East India Company's administrative tenure in India in the wake of the revolt of 1857, the Queen's proclamation announced the sovereignty of the Crown over British India declaring: "all shall alike enjoy the equal and impartial protection of the Law...And it is our further Will that, so far as may be Our Subjects, of whatever Race or Creed; be freely and impartially admitted to Offices in Our Service, the Duties of which they may be qualified, by their education, ability and integrity, duly to observe. ${ }^{3}$

The significance of the proclamation is supported by Irina Spector-Marks, who maintains that Queen Victoria’s ‘declaration that Indian subjects were due equal rights with Whites was frequently referred to as "the charter of Indian Liberty" or "the Indian's own 'Magna Carta'."'4 Scholars of the history of the South Asian community in Australia have explored their identification as British subjects. ${ }^{5}$ There has also been some work on this in regard to the Aotearoa New Zealand South Asian community. ${ }^{6}$ A co-authored article by Andrew Smith and Jatinder Mann was the first major work to look at the South Asian community in Canada exclusively in this respect. ${ }^{7}$ The South African South Asian community has the least work undertaken on this issue, with scholars mainly focusing on Mahatma Gandhi's views on British subjecthood rather than the broader South Asian community. ${ }^{8}$ To date no study has

\footnotetext{
${ }^{3}$ Quote taken from Sukanya Banerjee, Becoming Imperial Citizens: Indians in the Late-Victorian Empire (Durham, NC: Duke University Press, 2010), 22.

${ }^{4}$ Quote taken from Irina Spector-Marks, “'The Indian's Own Magna Carta': Britishness and imperial citizenship in diasporic print culture, 1900-1914," Journal of Colonialism and Colonial History 16, no. 3 (2015): 5.

${ }^{5}$ A prominent recent example is Margaret Allen, "I am a British subject': Indians in Australia claiming their rights, 1880-1940," History Australia 15, no. 3 (2018): 1-20. Kama Maclean also explores this in her recent monograph, British India, White Australia (Sydney, NSW: UNSW Press, 2020) which looks at the triangular relationship between Britain, India, and Australia.

${ }^{6}$ Sekhar Bandyopadhyay, "A History of Small Numbers: Indians in New Zealand, c. 1890s-1930s," New Zealand Journal of History 32, no. 2 (2009): 150-168.

${ }^{7}$ Andrew Smith and Jatinder Mann, "Civic Nationalism, Imperial Identities, and Punjabi Migration: Sundar Singh's Political Activism in the Dominion of Canada," South Asia: Journal of South Asian Studies, vol., 39, issue 2 (June 2016): 305-328.

${ }^{8}$ A. Desai and G. Vahed, The South African Gandhi: Stretcher-Bearer of Empire (Stanford, CA: Stanford University Press, 2015).
} 
looked at the identification of South Asians as British subjects in the four Dominions of Australia, Canada, Aotearoa New Zealand, and South Africa collectively, or compared their experiences, which is what this article will do. ${ }^{9}$

\section{The South Asian diaspora in Australia, 1900s-1940s}

According to Kama Maclean, 'By the 1890s, there was a small but growing British Indian population spread across the Australian colonies - a little over 5,000 - that became the target of an increasingly virulent politics.' She adds that 'The presence of Indians in Australia was central to the parliamentary debates leading up to the passing of the Immigration Restriction Act in 1901 (which effectively extended antiChinese legislation to all "Asiatics"), as well as to subsequent amendments to it.'10 Most South Asians resident in Australia in the late nineteenth century were from the greater Punjab, Madras, and the North West Frontier, as adventurous migrants explored the opportunities in the colonies, beginning a process of chain migration. ${ }^{11}$ Margaret Allen quite rightly argues that 'Indians is a highly problematic term....Many of the men who came to Australia hailed from the Punjab, parts of which are now in Pakistan...In Australia, they were often referred to, erroneously, as Afghans. ${ }^{\prime 2}$ It is for this reason that I use the term 'South Asian' in this article rather than 'Indian'. Building on this and other work by Allen I will show how South Asian migrants in Australia (the vast majority of whom came to the country before the introduction of

\footnotetext{
${ }^{9}$ There is however scholarship that has looked at the South Asian diaspora in a broader perspective. Examples of this include Brij V. Lal, Peter Reeves, and Rajesh Rai, Eds., The Encyclopedia of the Indian Diaspora (Singapore: National University of Singapore, 2006) and Robert A. Huttenback, Racism and Empire: White Settlers and Coloured Immigrants in the British Self-Governing Colonies, 1830-1910 (Ithaca: Cornell University Press, 1976).

${ }^{10}$ Quotes taken from Kama Maclean, "Examinations, access, and inequity within the empire: Britain, Australia and India, 1890-1910," Postcolonial Studies 18, no. 2 (2015): 116.

${ }^{11}$ Maclean, "Examinations, access, and inequity within the empire," 118.

${ }^{12}$ Quote taken from Margaret Allen, 'A fine type of Hindoo' meets 'The Australian type': British Indians in Australia and diverse masculinities," in Transnational Ties: Australian Lives in the World, eds. Desley Deacon, Penny Russell and Angela Woollacott (Canberra: ANU E-Press, 2008), 43-44.
} 
restrictive immigration legislation, or as it was more commonly known, the White Australia Policy in 1901) used their status as British subjects to lobby for more rights from the Australian state and federal governments. ${ }^{13}$ One of the earliest petitions from South Asian migrants along these lines was from a community of Sikhs in Western Australia to Sir Gerard Smith, Governor of Western Australia in 1898: We respectfully beg to draw Your Excellency's attention to the fact that the petition has one motive for its object, and that is showing that the Sikhs are naturally British subjects, and that their fortunes, lives, and existence are bound up in the welfare of the British nation...That being so, they are only asking for a common right with the colonist to uphold the dignity and integrity of the British Empire...We beg to offer to you our assurances of loyalty and respect to the throne and person of Her Imperial Majesty Queen Victoria, the Sovereign of the Sikhs, and to Your Excellency as the Viceroy of the most powerful Monarch in the world. ${ }^{14}$

So, their self-identity as British subjects and membership of a British nation was stressed and their loyalty to the British Crown was emphasised.

The official organisation advocating for South Asian migrants in Australia to be treated fairly by governments on the basis of their status as British subjects was the Austral-Indian Society ${ }^{15}$ in Melbourne, Victoria. The Secretary of the society was actually a white Australian, who had been born and raised in India, A. H. Pritchard. In a letter to the Marquess of Crewe, the Secretary of State for India on 4 January 1912 he asked for South Asian migrants to Australia who had arrived in the country before the White Australia policy was introduced to be allowed to return after they had gone to South Asia for a visit:

\footnotetext{
${ }^{13}$ Allen, "'I am a British subject': Indians in Australia claiming their rights, 1880-1940," 2.

${ }^{14}$ Quoted in Joyce Westrip and Peggy Holroyde, Colonial Cousins: A Surprising History of Connections Between India and Australia (Adelaide: Wakefield Press, 2010), 159.

15 There may very well have been other informal organisations that were active in Australia. However, the archive in the UK unsurprisingly only showed correspondence with official organisations. My future research in Australia will hopefully illustrate the former.
} 
I have the honour respectfully to address you on behalf of those Indians, British subjects who had resided in the Commonwealth for over and above the period of five years, prior to federation, and the passing of the Immigration Restriction Act of 1901-5, and who left for a sojourn in India, and are desirous of returning to the Commonwealth. Claiming that they had been domiciled here, and being unaware of the passing of the Restriction Act, they had frequently applied to the shipping companies at Bombay for passages to Australia, when they were told that unless they had exemption certificates issued in their favour they could not obtain passages to Australia; it was then that these poor illiterate men, unable even to read or write their own language, much less English, came to the knowledge that they were debarred from returning to their home of choice, "Australia." ${ }^{16}$

Pritchard also petitioned for South Asian migrants in Australia to be allowed to have the right to vote and be added to the electoral roll, as well as their wives in South Asia to be allowed to join them in the country. ${ }^{17}$

Later that same month the broader membership of the Austral-Indian Society wrote to the Marquess of Crewe themselves via their Secretary, Pritchard. In their letter they began with outlining the general distribution of South Asian migrants across Australia and the main occupations that they were engaged in. Although these varied they stressed that they all shared the same status of British subjects. ${ }^{18}$ They also drew attention to the prejudicial treatment that British subjects of South Asian descent in Australia received from the police and courts compared to white Australians:

The police are much against our fellow subjects, for when cases occur in the country districts and the person charged is an Indian, they go dead against him, and will not obtain the services of an interpreter for him, unless the magistrate orders them. As you will know, these

\footnotetext{
${ }^{16}$ National Archives of the UK (Hereafter NAUK), Colonial Office (Hereafter CO) 886/6/1, A. H. Pritchard, Secretary, The Austral-Indian Society to His Majesty's Secretary of State for India, 4 January 1912, 5.

17 Ibid., 5.

${ }^{18}$ NAUK, CO 886/6/1, The Austral-Indian Society to His Majesty's Secretary of State for India, 29 January $1912,4$.
} 
poor fellows, when charged with a serious offence, get quite excited, cannot at the best of times express themselves and make themselves understood in English, knowing nothing of the law and the court procedure. But when the poor fellow is committed for trial, i.e. he is to be tried before a judge and judge, strange to say, the Crown law authorities invariably engage an interpreter. He does only then receive justice, but if found guilty there is really no mercy shown him, so markedly severe is the treatment meted out to them in comparison to that of the white man. ${ }^{19}$

Joyce Westrip and Peggy Holroyde assert that 'An echo of earlier pleas for "fair play, bonnie play" can be heard in a letter from Shaikh Abdul Kader of Carlton, one of Melbourne's famous inner-city suburbs.... In 1918 he too was appealing to Aussies for a "fair go, India having been a loyal member of the Empire, fulfilling her obligations during the war against Germany".'20 Kader stressed the British identity of South Asians in Australia with his further comment that 'as Britishers we should have certain rights in preference to aliens...I do not think white is any more credit to humanity than brown or black. ${ }^{.1}$ Kader's motivation in sending the letter was 'to appeal to the persons in power in Australia to grant us certain rights which are denied us on the grounds of our being Asiatic...We should be allowed to vote, and also we should have the benefit of old age and invalid pensions. ${ }^{.22}$

Many of the calls for equal treatment by South Asian migrants to Australia on the basis of their status as British subjects above were taken up by a representative of the Government of India, V. S. Srinivasa Sastri, who visited Australia, as well as Aotearoa New Zealand, and Canada in 1922:

The primary object of my mission to Australia as well as to the other Dominions was to induce the respective Governments to give practical effect to the resolution of the Imperial

\footnotetext{
${ }^{19}$ NAUK, CO 886/6/1, The Austral-Indian Society to His Majesty's Secretary of State for India, 29 January 1912, 4.

${ }^{20}$ Quoted in Westrip and Holroyde, Colonial Cousins, 169.

21 lbid., 170.

$22 \mathrm{lbid}$.
} 
Conference of 1921 which recognised "that there is an incongruity between the position of India as an equal member of the British Empire and the existence of disabilities upon British Indians lawfully domiciled in some parts of the Empire," and recommended that "in the interests of the solidarity of the British Commonwealth it was desirable that the rights of such Indians to citizenship should be recognized."23

The Government of India sent a further representative, Dewan Bahadu Rangachariar, to Australia to lobby the Australian government to remove any remaining disabilities against South Asian British subjects in Australia in 1927. One of the remaining issues was the inability of South Asians to secure land leases under the South Australian Migration and Reclaimed Lands Act. When Mr. Sastri had previously visited Australia he had made the case for a change to the South Australian government. Mr. Rangachariar now made a representation to the Premier of South Australia, Mr. Richard Butler. He subsequently heard from Butler that the inability to lease land had been removed, as an amendment of the law had taken place, with the result that all British subjects were now able to secure leases. ${ }^{24}$

Westrip and Holroyde assert that 'The Indian presence had come of age...The Federal Government (now in charge of immigration matters uniformly in all the new States) gave all Indians the vote in 1925, as well as age-pensions and the right to bring in their wives and children on the same basis as migrants from the mother country. ${ }^{25}$ Allen puts the issue of the identity of South Asian migrants in Australia in a broader geographical context with 'Their status as British subjects allowed for trans-colonial and transnational connections with other Indians in the diaspora, but it complicated the forging of alliances with other deemed "prohibited

\footnotetext{
${ }^{23}$ British Library (Hereafter BL), India Office Records (Hereafter IOR)/L/E/7/1260, File 650, Report by V. S. Srinivasa Sastri, P.C. regarding his deputation to the Dominions of Australia, New Zealand and Canada, 1.

${ }^{24} \mathrm{BL}, \mathrm{IOR} / \mathrm{L} / \mathrm{E} / 7 / 1260$, File 650, Extract from the Pioneer Mail, 25 October 1927.

${ }^{25}$ Quote taken from Westrip and Holroyde, Colonial Cousins, 171.
} 
immigrants' in Australia...Despite their efforts, their status as British subjects was not really honoured in Australia. ${ }^{26}$

This section on the South Asian community in Australia has predominantly focused on South Asians who migrated to Australia from the mainland of British India, and usually more often than not the northern part of the country. However, future research in Australia might very well reveal more about South Asians who migrated from Goa in Southern British India and even Sri Lanka, or Ceylon as it was known at the time.

\section{The South Asian diaspora in Canada, 1900s-1940s}

Many South Asian migrants in Canada also demonstrated a strong identity as British subjects. This is illustrated by the agreed deliberations of 'British Indian subjects residing in the Dominion of Canada, assembled in a public meeting held [in]...Fairview[, British Columbia]' on 24 April $1910 .{ }^{27}$ One of the main areas of criticism that the meeting highlighted was the disabilities placed upon South Asian migrants arriving in Canada, compared to other British subjects and even non-British subjects:

The present Dominion Immigration Laws are quite inconsistent to the Imperial policy, because they discriminate against the people of India, who are British subjects; as they are forced to produce a sum of $\$ 200.00$ before landing, whereas the other British subjects are not...The present Dominion Immigration Laws are humiliating to the people of India, when the aliens, such as the Japanese, by the treaty rights can come to Canada showing a very small amount

\footnotetext{
${ }^{26}$ Quote taken from Allen, “'I am a British subject," 20.

${ }_{27}$ NAUK, CO 886/4/1, No, 12. Canada. India Office to Colonial Office, Received 2 June 1910, Enclosure in No. 12, 9.
} 
of $\$ 30$ to $\$ 50$, whereas, we, the fellow British subjects, are not allowed to enjoy the birthright of travelling from one part of the British Empire to the other. ${ }^{28}$

The meeting also criticised the continuous journey provision introduced against primarily South Asian migrants by the Canadian federal government, whereby they had to have a through ticket from their land of birth or of citizenship and the government soon after ended the only steamship line from India to Canada: 'As long as we are British subjects any British territory is the land of our citizenship from the interpretation of the Imperial...Government...the narrow interpretations of the Dominion Government about the land of citizenship do not allow us to enter Canada from London, Hong Kong, Shanghai, and other parts of the British Empire. ${ }^{29}$ The meeting hit its point home by comparing the treatment South Asian migrants to Canada received compared to non-British territories they had also moved to:

We appeal and most forcefully bring to your notice that no such discriminating laws are existing against us in foreign countries like the United States of America, Germany, Japan, and Africa, to whom we do not owe any allegiance whatsoever. Under these circumstances we must respectfully implore a favourable consideration and prompt amendment of the unfair laws which impress us that we enjoy better privileges under foreign flags than those under the British flag. ${ }^{30}$

In a memorandum on matters affecting the South Asian community in British Columbia by Colonel E. J. E. Swayne, Governor of British Honduras in 1909 the coming together of different communities, both cultural and religious in Canada was highlighted:

It is a matter of considerable interest to trace the growth of a combined sentiment between the various classes of Hindus [this was a term often used by whites in a broader sense to

${ }^{28}$ NAUK, CO 886/4/1, No, 12. Canada. India Office to Colonial Office, Received 2 June 1910, Enclosure in No. 12, 9.

${ }^{29} \mathrm{lbid}$.

$30 \mathrm{lbid}$. 
describe South Asians in general, as the historical name for the Indian subcontinent was Hindustan] in Vancouver. They have coalesced from the common need of protection against the hostility of white labour, and Punjabi-Mohamedans, Sikhs, and Hindus from the Punjab, and Brahmins from the north-west from lower Bengal, have been brought together in a way that could not have happened in India. ${ }^{31}$

Thus, their common experience of living amongst a majority group of white Canadians emphasised to them that they were all South Asian and faced similar challenges.

The following year, one of the leading South Asian organisations in Canada, the Hindu Friend Society of Victoria sent a petition to the Colonial Office in London, UK. One of the main demands was the following:

The families of those men who have settled in British Columbia ought to be allowed to enter this country on the same terms as the Japanese, Chinese, or even Negroes. At present an Order in Council requires a Hindu to come direct from the land of his birth, and as there is no direct steamship communication between India and Canada, this law is a legal absurdity, for people cannot perform what is, on the face of it, impossible. Your petitioners note that this Order in Council, No. 920, has been suspended just at present in the case of aliens, and we respectfully submit why should it not be rescinded for these our fellow-subjects? ${ }^{32}$

The petition got to the crux of the matter when it came to South Asian migrants to Canada being treated differently compared to other fellow British subjects:

Does Imperialism mean Canada for the Empire, Australia for the Empire, India for the Empire, or can there be two subjects of one and the same Empire? If there is but one recognized definition under the flag over which the sun is supposed to never set, then it is for us to see

\footnotetext{
${ }^{31}$ NAUK, Dominion Office (Hereafter DO) 35/1122/26, Memorandum on matters affecting the East Indian Community in British Columbia by Colonel E. J. E. Swayne, 7.

${ }^{32} \mathrm{BL}$, IOR/L/PARL/2/369, Imperial Conference, 1911. Dominions No. 7. - Minutes of Proceedings of the Imperial Conference, 1911, No. 2. Canada. Hindu Friend Society of Victoria, British Columbia to Colonial Office, 28 April 1911, 279-281.
} 
that no injustice shall minimize the rights or privileges of that citizenship, whether the holder is black or white. ${ }^{33}$

The petition ended with the following question: 'is it just, is it right...that we, as subjects of one the same realm, should condemn any of our fellow subjects to degrading conditions such as your petitioners humbly submit, and which the Canadian Hindus have patiently endured for the past six or seven years.'34

The Hindu Friend Society of Victoria followed up with another petition to the India Office in London, UK, which was forwarded to the Colonial Office in June 1911. Again they emphasised their loyalty to the British Empire: 'As loyal citizens of the Empire we feel that such invidious treatment is not calculated to promote the best interests of the Empire which we all have at heart, and we therefore most earnestly pray that these disabilities be removed. ${ }^{35}$ Interestingly the petition added that 'Whereas as the interests of Hindus and Mahomedans are identical, we, the Mahomedans living in Canada and assembled in this meeting, declare that we are at one with the Hindus in approving all the resolutions passed in this meeting. ${ }^{36}$ So, again the experience of living amongst a majority white population, led to South Asians of different faiths, seeing themselves as South Asian first and foremost.

The pressure was kept up with further representations being made, this time to the Minister of the Interior in Ottawa by delegates of the United India League and the Khalsa Diwan Society on 15 December 1911. They began with the hope that the Canadian government was "prepared to recognize the solemn promises made by their Majesties, Queen Victoria, King Edward, and King George of India, which India

\footnotetext{
${ }^{33} \mathrm{BL}, \mathrm{IOR} / \mathrm{L} / \mathrm{PARL} / 2 / 369$, Imperial Conference, 1911. Dominions No. 7. - Minutes of Proceedings of the Imperial Conference, 1911, No. 2. Canada. Hindu Friend Society of Victoria, British Columbia to Colonial Office, 28 April 1911, 279-281.

$34 \mathrm{lbid}$.

${ }^{35}$ NAUK, CO 886/4/1, No. 26. Canada. India Office to Colonial Office, 28 June 1911, Enclosure in No. 26, Hindu Friend Society of Victoria, British Columbia to India Office, 22.

$36 \mathrm{lbid}$.
} 
is an integral part of our Empire, that all their subjects shall be treated alike. ${ }^{37}$ I would emphasise the use of the phrases our Empire and their subjects. Building on this opening they asserted that:

Our first claim for consideration at the hands of your Honourable Government is that we are British subjects, of proven loyalty. More than 90 per cent, of the Hindustanees in Canada are Sikhs. With the name Sikh is linked up fidelity and heroic loyalty to the Empire. We instance the Indian mutiny, Africa, Afghanistan, Burma, and Somaliland. In other words, whenever the Empire needed in the past or may in the future need loyal hearts to protect or preserve her honour, the Sikh has always been ready in the past to give willing service to the Empire. A large number of these men now in Canada have seen active service, and many among them have medals for special bravery. ${ }^{38}$

I would highlight the new specific emphasis on the fact that the majority of South Asian migrants in Canada were Sikhs, and that their loyalty to the British Empire had been demonstrated in several military campaigns. The much hated Continuous Journey provision was also criticised, again on the basis of unequal treatment being meted out to fellow British subjects: 'Is there any process or law or regulation that can be directly used to justly strip a loyal British subject of his right to travel in any part of the Empire?...Our common Sovereigns, their Majesties mentioned in these restrictions, have solemnly promised all subjects of the Empire, regardless of race, equality of treatment.'39

In a report from the Colonial Office to the India Office in October 1914 on 'Disabilities suffered by the Hindus in Vancouver, British Columbia' a recommendation was made that 'If a British Indian officer of superior standing was appointed here [Canada] with reasonable powers from the Dominion Government,

\footnotetext{
${ }^{37}$ NAUK, CO 886/7/5, The representations made to the Ottawa Government by the delegates of the United India League and the Khalsa Diwan Society, Vancouver, B.C., on the $15^{\text {th }}$ December, 1911, 32.

38 Ibid.

$39 \mathrm{lbid}$.
} 
he could adjust many matters for the immigrants to their betterment and satisfaction, and it would be felt that the British Government had some interest in their subjects when away from home. ${ }^{\cdot 40}$ During the First World War, the issue of conscription in Canada also provided an opportunity for South Asian migrants in the country to highlight the unfair way in which they believed they were being treated, but at the same emphasising their loyalty to the British Crown:

The conscription law can be applicable to the Canadian citizens only and not to us, the Hindus, as we are not citizens of this country and have not been enjoying the full rights as real citizens, and moreover have no hand or voice whatsoever of any nature in the legislation of this country...We are loyal to the heart, however, and wish the success of the British arms, and will do, and have been doing, our best for the cause..$^{41}$

In a memorandum by Sir Satyendra Prasanna Sinha, Under-Secretary of State for India in May 1919, it was again stressed that the disability imposed on the Sikh settlers in Canada, numbering about 4,000 men, of not being allowed to bring their wives and minor children to live with them is a very real and serious hardship'42 and he added that it had 'caused acute dissatisfaction among perhaps the most prominent martial race in India, and those who have flocked with the greatest alacrity to the Indian Army for the defence of the Empire. ${ }^{13}$ Hence, the identity of Sikh migrants in Canada as integral members of the British Empire was emphasised again.

Hugh Johnston maintains that the 'Freedom to come and go, to live and work in the British Empire was a right that Punjabi Sikhs and other immigrants from India claimed when they first came to Canada...They claimed it as British subjects and

\footnotetext{
${ }^{40}$ NAUK, CO 886/7/5, No. 112. Canada. Colonial Office to India Office. Enclosure in No. 109. Disabilities suffered by the Hindus in Vancouver, British Columbia, 31 October 1914, 86.

${ }^{41}$ NAUK, CO 886/8/7, Extract from the Vancouver Province, 13 November 1917, 18.

${ }^{42}$ BL, IOR/L/E/7/1183, No. 2754. Government of India. Department of Commerce and Industry. Emigration. Resolution, 9 May 1919, Annex I :- Memorandum by Sir S. P. Sinha, 2. 43 lbid.
} 
continued to claim it - without success - until India achieved her independence, after which they began to be heard with more respect.'44 Maia Ramnath argues that:

When Mangu Ram [a leader of Chamar or lower caste South Asians] returned to India....in 1926, he found that his years abroad [in Canada] had changed his bearing to the extent that he now passed for a person of higher caste..."For sixteen years abroad he had enjoyed a life in which he was treated as an individual rather than as a Chamar," [of lower caste] remarks Mark Juergensmeyer, noting that while the Indian community in North America faced external racism, they were internally egalitarian to a degree unheard of within India. ${ }^{45}$

\section{The South Asian diaspora in Aotearoa New Zealand, 1900s-1940s}

Out of all the four case studies in this article, the number of South Asian migrants in Aotearoa New Zealand was the smallest. In Sekhar Bandyopadhyay's article on the history of the South Asian community in Aotearoa New Zealand entitled 'A History of Small Numbers: Indians in New Zealand', he maintains that the main reason why the history of the community was never a part of the mainstream story of the nation was because of its small numbers, which was the case during the whole colonial period and did not really change until the 1990 s. ${ }^{46}$

In a report by Sastri on his visit to the South Asian communities in Australia, Aotearoa New Zealand, and Canada the following observation was made:

The resident Indians in the Dominion of New Zealand number between 550 and 600. Exact figures were unfortunately not forthcoming and the Census Department had not completed their report of the last census. The New Zealand Electoral Act gives franchise to all British

\footnotetext{
${ }^{44}$ Quote taken from Hugh J. M. Johnston, The Voyage of the Komagata Maru: The Sikh Challenge to Canada's Colour Bar (Vancouver: UBC Press, 2014), 3.

${ }^{45}$ Quote taken from Maia Ramnath, Haj to Utopia: How the Ghadar Movement Charted Global Radicalism and Attempted to Overthrow the British Empire (Berkeley, CA: University of California Press, 2011), 234.

${ }^{46}$ Bandyopadhyay, "A History of Small Numbers," 151.
} 
subjects, and Indians, enjoy the privilege, just the same as other classes of His Majesty's subjects. ${ }^{47}$

Although they had the franchise, South Asians in Aotearoa New Zealand did suffer other disabilities. They were excluded from the old-age pension, they were discriminated against in various other ways (e.g. work, accommodation, informally including the discourse used), and the 1920 Immigration Restriction Act was discriminatory. Sastri did though emphasise the status of South Asian migrants in the country as British subjects. However, he did see some problems, which Sastri also felt were common to Australia, and suggested a solution for the South Asian communities in both countries:

It is the absence of a co-ordinating protecting agency which could help the Indian community to realise its existence as a corporate entity, and assist individual members of the community in combatting difficulties which arise from day to day. Neither in Australia nor in New Zealand do Indians possess sufficient education to take care of themselves. They are scattered over a wide area; they are drawn from various classes, and they lack the equipment for organized effort. $^{48}$

Bandyopadhyay in reference to the deteriorating situation of South Asians in South Africa argues that 'The New Zealand media reported all these events routinely, as Indians vigorously claimed rights "granted to them by Queen Victoria" to enter any part of the empire as British subjects and protested loudly against their mistreatment in the "overseas dominions of the Crown", including Australia and New Zealand.'49 So, South Asian migrants in one particular country were very much aware of what was going on with other members of the global South Asian diaspora.

\footnotetext{
${ }^{47}$ BL, IOR/L/E/7/1260, Report by V. S. Srinivasa Sastri, P.C. regarding his deputation to the Dominions of Australia, New Zealand and Canada, 7.

48 Ibid., 9.

${ }^{49}$ Quote taken from Bandyopadhyay, "A History of Small Numbers," 157.
} 
The first ethnic organisations among South Asian migrants in Aotearoa New Zealand were established by early Indian migrants. Although they were aware of caste, ethnic, and religious distinctions, they saw themselves as one group when confronted by prejudice from broader Aotearoa New Zealand society. The Auckland Indian Association was established in 1918 in reaction to racist attacks. ${ }^{50}$ Jacqueline Leckie illustrates that 'Indians did not meekly accept the anti-Asian venom of the White New Zealand League, formed in 1925, and established the New Zealand Indian Central Association in 1926. ${ }^{51}$ South Asian organisations were also set up in other areas, offering cultural and social assistance together with fighting against prejudice. Common to the South Asian communities in Australia and Canada, immigration policy and practice was closely followed by the organisations. ${ }^{52}$ Leckie asserts that 'The Indian associations have been an important site for the reproduction of ethnic identity... They have reflected the dominant composition of early South Asian settlement in New Zealand, reinforcing Gujarati religious, language, and kinship ties. ${ }^{53}$

Hew McLeod focuses on the Punjabi community in Aotearoa New Zealand. He maintains that the practical realities of the situation that faced Punjabi migrants of different castes when they arrived in Aotearoa New Zealand and undertook heavy manual labour in remote areas in labouring gangs meant that 'Gang membership involved a sharing of cooking responsibilities and the presence of Chamars within a gang meant that men from other castes would eat food which Chamars had

\footnotetext{
50 Jacqueline Leckie, "South Asians: Old and New Migrations," in Immigration and National Identity in New Zealand: One People, Two Peoples, Many Peoples?, ed. Stuart William Greif (Palmerston North: Dunsmore Press, 1995), 154.

${ }^{51}$ Quote taken from Leckie, "South Asians," 154.

52 Leckie, "South Asians," 154-155.

53 Quote taken from Leckie, "South Asians" 155.
} 
prepared. ${ }^{54}$ So, caste distinctions were not maintained in this situation. However, McLeod asserts that there is also evidence for the contrary argument, that caste awareness continued in Aotearoa New Zealand. Some migrant Chamars enthusiastically supported the Ad Dharm movement, which was a movement of protest headed by Mangoo (his first name is spelt in different ways, probably reflecting the various way in which white immigration officers recorded it) Ram, a Chamar from Hoshiarpur, Punjab, aimed to set up for the Untouchable community a distinct identity, apart from that of Hindus, Muslims, and Sikhs. ${ }^{55}$ So, the creation of a pan-South Asian identity amongst South Asian migrants in Aotearoa New Zealand was a mixed picture, depending on the particular situation of the group in question. Leckie puts the movement of South Asian migrants to Aotearoa New Zealand in a global perspective as she points out that they were a part of a broader South Asian diaspora. But in contrast to a majority of South Asian migrants at this time, they were not indentured labourers. ${ }^{56}$ She also reflects on the bonds that were built amongst South Asian migrants, from diverse parts of the continent on the long ocean journeys to Aotearoa New Zealand:

Jahaji (or jahazi in Punjabi) refers to the bonds that develop between fellow travellers and such solidarity planted the seeds of the New Zealand community...Although they came from vastly different regions of the Indian subcontinent, from diverse villages, castes, classes and religions and although they spoke different languages, migrants were thrown together on the ships that sailed to the South Pacific. ${ }^{57}$

According to Bandyopadhyay, 'The Indian community in New Zealand was numerically small, and socially more homogenous and economically marginal in the

\footnotetext{
${ }^{54}$ Quote taken from Hew McLeod, Punjabis in New Zealand: A History of Punjabi Migration, 18901940 (Amritsar: Guru Nanak Dev University, 1986), 109.

${ }_{55}$ McLeod, Punjabis in New Zealand, 110.

${ }^{56}$ Jacqueline Leckie, Indian Settlers: The Story of a New Zealand South Asian Community (Dunedin: Otago University Press, 2007), 21.

${ }^{57}$ Leckie, Indian Settlers, 31.
} 
pre-war period...At this time, an important feature of Indian labour migration, both internal as well as external, was its highly structured nature. ${ }^{58} \mathrm{He}$ adds that through a "process of "othering" the Asian ethnic minorities through overt racial discrimination and attacks confirmed the community bonds among the immigrant Indians, and alerted them to the need to form their own organisations to voice their protests and assert their rights. ${ }^{159}$ Therefore, the South Asian migrants living in Auckland and the surrounding areas established an association in 1918, those in Wellington created the Wellington Indian Association in 1925, and the Country Section Indian Association was formed in Taumarunui in 1926. The community also thought that activities should be coordinated across the regions, and so a conference took place at Taumarunui on 20 July 1926, at which it was resolved to establish a New Zealand Central Association, which the other local groups would be affiliated with. It is noteworthy that the Taumarunui conference referred to Queen Victoria's proclamation of 1858 and called for South Asian migrants to be treated as equal British subjects. ${ }^{60}$

Kapil Tiwari also reflects on the formation of the New Zealand Central Association and maintains that it 'was thought necessary to preserve the sense of unity among the various sections of the community consisting of the Gujarati Hindus, Punjabi Sikhs, Indian Muslims and a small number of Indian Christians and Parsis. ${ }^{61}$ He adds that it should be noted...that all of them exhibited a strong unifying force and decided unanimously to organise an Association to look into the interests of all

\footnotetext{
${ }^{58}$ Quote taken from Sekhar Bandyopadhyay, "Reinventing Indian Identity in Multicultural New Zealand," in Asia in the Making of New Zealand, eds. Henry Johnson \& Brian Moloughney (Auckland: Auckland University Press, 2006), 126.

${ }^{59}$ Quote taken from Bandyopadhyay, "Reinventing Indian Identity in Multicultural New Zealand," 128.

${ }^{60}$ Bandyopadhyay, "Reinventing Indian Identity in Multicultural New Zealand," 128-129.

${ }^{61}$ Quote taken from Kapil N. Tiwari, "The Indian Community in New Zealand: A Historical Survey," in Indians in New Zealand: Studies in a sub culture, ed. Kapil N. Tiwari (Wellington: Price Milburn, 1980), 12.
} 
Indians regardless of their religious and ethnical beliefs.' 62 The New Zealand Indian Central Association was legally registered in the Supreme Court of Aotearoa New Zealand on 18 July 1927 . Two of the goals of the association were: to supply the tools and resources for South Asians to secure their full rights as British subjects in Aotearoa New Zealand and to maintain the pride and moral reputation of India in Aotearoa New Zealand to encourage more positive interactions between South Asian migrants and other British subjects in the country. ${ }^{63}$ So, South Asian migrants' identity as British subjects was emphasised yet again.

According to Leckie:

Common occupations with a shared, almost corporate, goal of economic and social advancement within the New Zealand and Indian context appear to have been fundamental to Indian and specifically Gujarati or Punjabi cohesion in New Zealand... This reflects not simply a sense of a shared community but also a common past rooted in the migration process and the experience of settlement abroad. ${ }^{64}$

In response to increasing white New Zealander hostility and with their community being so small, close co-operation and assistance amongst South Asian migrants in Aotearoa New Zealand were a form of survival and protest. Living, working, and relaxing together as a South Asian community was commonplace in the early period of settlement. So, it is unsurprising that in a society such as Aotearoa New Zealand, where South Asians were such a small community, caste as a strict structured system of economic and social relations was not recreated (although several commentators have remarked that factional groupings, loosely based on caste, did spread through associations). The migration of only particular castes to Aotearoa

\footnotetext{
62 Ibid.

63 Tiwari, "The Indian Community in New Zealand," 14-15.

${ }^{64}$ Quote taken from Jacqueline Leckie, "From Race Aliens to an Ethnic Group - Indians in New Zealand," in Ethnicity and Nation Building in the Pacific, ed. M. C. Howard (Tokyo, 1990), 182.
} 
New Zealand only strengthened this. ${ }^{65}$ So, again there is a sense of the existence of a pan-South Asian identity amongst South Asian migrants in Aotearoa New Zealand, which was in response to their living in a society that had a majority white population.

\section{The South Asian diaspora in South Africa, 1900s-1940s}

The amount of material on the South Asian community in South Africa is by far the largest out of all the four case studies of this article. This is primarily for two reasons: the South Asian community in that country was the largest (numbering in the hundreds of thousands) and they had also been there for the longest time (since about 1860). In a letter to the Secretary of State for the Colonies, the Marquess of Crewe from the South Africa British Indian Committee on 20 July 1911, a request for a deputation of the committee to General Louis Botha (Prime Minister of South Africa at the time) who would be in London, UK at the Imperial Conference was made. Amongst other things the committee wanted 'to invite him [Botha] to deal...with...matters affecting the treatment and privileges to be extended to British Indian subjects in that portion of the Empire. ${ }^{\prime 66}$ Thus, the identity of South Asians in South Africa as British subjects was stressed. This was also the case in a petition by teachers and ex-teachers of Government-aided South Asian Schools in Natal that same year. ${ }^{67}$

A mass meeting of South Asians was held under the auspices of the Hamidia Islamic Society in the Hamidia Hall, Vrededorp, the Transvaal in January 1916. Mr. Jahee Essop Ismail Mia, the Chairman, 'contended that it was of transcendental

\footnotetext{
${ }^{65}$ Leckie, "From Race Aliens to an Ethnic Group - Indians in New Zealand," 182, 188-189.

${ }^{66} \mathrm{BL}, \mathrm{IOR} / \mathrm{L} / \mathrm{PJ} / 6 / 1062$, File 209, Telegram from South Africa British Indian Committee to The Under Secretary of State, India, 20 July 1911 (including copy of letter addressed to the Secretary of State for the Colonies), 2.

${ }^{67} \mathrm{BL}, \mathrm{IOR} / \mathrm{L} / \mathrm{PJ} / 5 / 462$, Various memoranda, minutes, and telegrams between the British and South African governments regarding Indians in South Africa, 1911.
} 
importance to exercise great restraint at the present critical hour in the history of the British Empire...As law-abiding, and above all, loyal, subjects of the King-Emperor, they must, he said, do nothing which would in the least degree add to the present difficulties of the Government.' ${ }^{68}$ This comment was obviously in the context of the First World War. The meeting ended with a resolution that 'This meeting take this opportunity to manifest its loyalty and devotion to the King-Emperor and the Empire.' ${ }^{\prime 2}$ So, the loyalty of South Asians in South Africa to the British Empire was highlighted. The British Indian League also expressed similar sentiments the following month, but added that it 'painfully recognizes that the immigration and Asiatic laws of this Province are unparalleled in the legislative enactments of any foreign civilized Governments in the world in respect of their own subjects, and that those laws are not carried out in the sympathetic manner as promised. ${ }^{70}$

There was a huge controversy over the status of some South Asians in South Africa as British subjects in February 1918, specifically those that had migrated from Princely states in British India, as reported in Indian Opinion:

The recent decision of the Natal Provincial Division of the Supreme Court raises a great question. By a stroke of the pen more than half of the Indian residents, born in India, are declared to be aliens and not British subjects. The Attorney-General, for the Immigrants Appeal Board, raised objection to the entry of an Indian, domiciled here since 1896, on the ground that he was not a British subject, but was a subject of the Native State of Bhawanagar, in India. ${ }^{71}$

\footnotetext{
${ }^{68}$ NAUK, CO 886/7/13, Extracts from Rand Daily Mail, 10 January 1916, "Indians and their grievances: Two Mass Meetings. Criticism of the Immigration Department," 3.

69 lbid.

${ }^{70}$ NAUK, CO 886/7/13, No. 5. The Governor-General to the Secretary of State, 16 February 1916, Enclosure 1 in No. 5, The British Indian League To His Excellency the Governor-General, Union of South Africa, 4.

${ }^{71}$ NAUK, CO 886/7/13, Extract from Indian Opinion, Friday 8 February 1918, 113.
} 
But the newspaper responded to this legal argument with 'If the subjects of Native States in India do not owe allegiance to King George, the Princes themselves certainly do... How it is possible for a Prince, who is not an alien, to rule over subjects who are aliens? The thing is preposterous. ${ }^{72}$ The British Indian League also expressed its concern over this legal decision that same month to the GovernorGeneral of South Africa, the Viscount Buxton:

In this matter I am respectfully venturing to address you, not as Governor-General of the Union...but as the representative of the King-Emperor of India. On the $6^{\text {th }}$ instant the Supreme Court of Natal, comprising of three English judges, pronounced a judgement to the effect that Indians born in the Native States of India are not British subjects. In the Delhi Coronation Durbar, His Majesty King George said to the Indian Princes and representative Indian people assembled therein: "You are my loyal subjects, men of valour, of proud lineage, and noble traditions." A similar proclamation was issued to the Princes and people of India by His Majesty King Edward. ${ }^{73}$

So, the identity of South Asians in South Africa as British subjects was emphasised yet again.

In May 1921 the British Indian Council in Port Elizabeth, Cape Province in a telegram to the Governor-General of South Africa expressed its strong opposition to further restrictions being placed on South Asian British subjects in South Africa: $10^{\text {th }}$ May, 1921. Mass Meeting, Sunday, protest against unjust humiliating spirit debates House of Assembly proceedings report Asiatic Inquiry Commission in touching point allocate distinct areas, both rural and urban, in Union; also view alarming feeling attitude touching compulsory and voluntary repatriation against law-abiding citizens of the British Empire, and further opposed against introduction drastic legislation detrimental to the wishes of the community, and seeks British fair play and justice. Community also suggested calling

\footnotetext{
72 NAUK, CO 886/7/13, Extract from Indian Opinion, Friday 8 February 1918, 113.

${ }^{73}$ NAUK, CO 886/7/13, No. 124. The Governor-General to the Secretary of State, Received $13^{\text {th }}$ May 1918, Enclosure 1 in No. 124, The British Indian League to the Governor-General of South Africa, 15 February 1918, 116.
} 
emergency Indian conference claiming status forthcoming Imperial Conference and League of Nations sympathy solicited to the law-abiding British citizen who had served the British traditions for a century and a half. ${ }^{74}$

The references to 'British fair play and justice' and South Asians in South Africa having 'served the British traditions for a century and a half' should be emphasised.

In February 1924 a deputation from the South African Indian Congress, which was a central body representing the Cape British Indian Council, British Indian Association of the Transvaal, Natal Indian Congress (NIC), and the Natal Indian League waited upon Patrick Duncan, Minister of the Interior, to express their opposition to the newly introduced Class Areas Bill by the Union government. ${ }^{75} \mathrm{Mr}$. Albert Christopher (Joint Secretary of the Natal Indian Congress) in particular made a very interesting point contrasting the status of South Asians who had arrived in South Africa as British subjects before they arrived in the country, compared to the situation with the Boers (the majority of the white population in the country, who were primarily of Dutch descent):

The Minister had referred to the predominating sentiment among the Europeans, but where had many of the Europeans come from? They had not been British subjects before they came to South Africa; and yet they now take a part in that predominating sentiment and took a share in the views which were held in regard to the Indians who were British subjects. ${ }^{76}$

So, Christopher was alluding to the fact that Boers, who had not been British subjects before they arrived in South Africa (and only became so once the British took control of their colonies) were deciding the fate of South Asians, who had been British subjects their whole lives.

\footnotetext{
${ }^{74}$ NAUK, CO $886 / 9 / 1$, No. 22, The Governor-General to the Secretary of State, (Received $31^{\text {st }}$ May, 1921), Enclosure in No. 22, British Indian Council, Port Elizabeth to Governor-General, Cape Town, 75.

${ }^{75} \mathrm{BL}, \mathrm{IOR} / \mathrm{L} / \mathrm{E} / 7 / 1183$, File 88(iii), Extract from the Cape Times, 16 February 1924, 14-15.

${ }^{76} \mathrm{BL}, \mathrm{IOR} / \mathrm{L} / \mathrm{E} / 7 / 1183$, File 88(iii), Extract from the Cape Times, 19 February 1924, 20.
} 
However, by 1930 the rhetoric of South Asian leaders in South Africa was starting to shift. There was little or even no reference to South Asians in South Africa's status as British subjects and more on their 'Indianness'. This was illustrated in the proceedings of the South African Indian Congress Emergency Conference held on 5-6 October 1930 in response to the Asiatic Tenure Bill introduced by the Union government:

I will be failing in my duty if I were not to extend a special welcome, at this our momentous Conference in the history of our people in this land, to the Agent of the Government of India, Sir K. V. Reddi. I am happy that he was able to be with us today, for the Indians in South Africa realise that in the Agent we have a true and faithful friend full of zeal, love, compassion for his brethren, who have been unfortunately placed in a position that calls for guidance from him in our most difficult period. ${ }^{77}$

Reference was also made to the previous bilateral agreement between the Government of India and the Union of South Africa on the status and treatment of South Asians in South Africa, known as the Cape Town Agreement of 1927: '[it] raised hopes in the minds of the Indian community in South Africa that the venomous head of racialism had been slain by the co-operation of the two Governments to bring peace and harmony where distrust and hate ruled. ${ }^{78}$ The absence of references to South Asians in South Africa's status as British subjects and more of an emphasis on their ethnicity as Indians and the role that the Government of India had played and could play in the future in their situation in the country, was probably a reflection of the fact that their status as British subjects had not seemed to make any difference in their opposition to restrictions placed upon them by the Union

\footnotetext{
${ }_{77} \mathrm{BL}, \mathrm{IOR} / \mathrm{L} / \mathrm{PO} / 1 / 10$, Proceedings of South African Indian Congress Emergency Conference held on $5^{\text {th }}$ and $6^{\text {th }}$ October, 1930, Chairman of the Reception Committee (Mr Cassim Adam: Transvaal Indian Congress), 1-2.

${ }^{78} \mathrm{BL}, \mathrm{IOR} / \mathrm{L} / \mathrm{PO} / 1 / 10$, Proceedings of South African Indian Congress Emergency Conference held on $5^{\text {th }}$ and $6^{\text {th }}$ October, 1930, Chairman of the Reception Committee (Mr Cassim Adam: Transvaal Indian Congress), 2.
} 
government in the past, and the Indian nationalist movement was growing in British

India. This new shift and emphasis was also demonstrated in a Statement of the South African Indian Congress presented to the Minister of the Interior on the question of his segregation scheme in February 1939. ${ }^{79}$

\begin{abstract}
According to Surendra Bhana:
The laws and practices that singled out Indians for differential treatment were opposed on the grounds that Indians as British subjects enjoyed protection under the doctrine of Imperial equality, and that Whitehall should uphold this principle in colonies under its control...The rights and privileges enjoyed by Indians as British subjects in India did not cease to exist when they moved to another part of the empire. ${ }^{80}$
\end{abstract}

The British Indian Association, together with the NIC used this argument. They both called on the British government not to acquiesce in legislation that was prejudiced against South Asian British subjects. ${ }^{81}$ Bhana also reflects on Gandhi's legacy in South Africa and suggests that he created an 'Indianness'. By striving to unify the different communities that arrived from India, he assisted a new pan-Indian or South Asian identity to rise. ${ }^{82}$ However, Bhana does also concede that:
Religion, language, and class differences have always been present in NIC politics...Those with passenger origins often considered themselves better pedigreed than Indians with indentured origins...The passenger Indians came mainly from western parts of India where Gujarati was spoken, and used the term 'Girmitiyas' to refer dismissively to indentured Indians; in the post-indentured period other terms were used with similar irreverence: 'Calcuttias' for Bhojpuri-speakers from the Ganges valley, and 'Maddrassis' for Tamil- and Teluga-speakers from the southern parts of India. ${ }^{83}$

\footnotetext{
${ }^{79}$ NAUK, DO 35/600/1, Statement of the South African Indian Congress presented to the Minister of the Interior on the question of his segregation scheme, 20 February 1939, 1.

80 Quote taken from Surendra Bhana, Gandhi's Legacy: The Natal Indian Congress, 1894-1994

(Pietermaritzburg: University of Natal Press, 1997), 18-19.

${ }^{81}$ Bhana, Gandhi's Legacy, 19.

82 Ibid., 31.

${ }^{83}$ Quote taken from Bhana, Gandhi's Legacy, 37.
} 
Moreover, the Colonial Born and Settler Indian Association (CBSIA) consisted of predominantly South Asians who were descended from indentured workers. Most of them were first generation South Africans who did not think of India as their home..$^{84}$ However, Robert Huttenback maintains that 'What would normally have been a far from cohesive community was progressively forced toward cooperation, at least in the political sphere, by a common set of disabilities. ${ }^{85}$ This was similar to the situation in the previous three case studies of this article.

\section{Comparisons}

First of all, numbers matter. As mentioned above the South Asian community in South Africa was the largest and it had also been there the longest, with second generations being present very early on in the period covered by this article. The next largest community was in Canada. Then it was in Australia and the smallest community of South Asians was in Aotearoa New Zealand. There were also different patterns of settlement by the South Asian communities in the four countries explored in this article. In South Africa and Canada these were both geographically concentrated, primarily in Natal and the Transvaal in the former, and British Columbia in the latter. In contrast, although their numbers were smaller, the South Asian communities in Australia and Aotearoa New Zealand were spread out across those countries.

Both of the above developments had an impact on organising within the South Asian communities in the four countries. There were much stronger organisations representing South Asians in South Africa and Canada, compared to Australia and

\footnotetext{
${ }^{84}$ Bhana, Gandhi's Legacy, 38.

${ }^{85}$ Quote taken from Robert A. Huttenback, Gandhi in South Africa: British Imperialism and the Indian Question, 1860-1914 (Ithaca, NY: Cornell University Press, 1971), 43.
} 
Aotearoa New Zealand. In the case of South Africa there were numerous organisations representing South Asian interests, which varied depending on the province of the country they were based in, and later on whether they represented mostly indentured workers and/or their descendants or South Asians who had come on passenger ships by independent means. In Canada there were several major organisations, such as the Hindu Friend Society of Victoria or the Khalsa Diwan Society. The South Asian community in Australia had one major official organisation representing them: the Austral-Indian Society, and interestingly its Secretary was someone of European descent, although they were born in India. Despite the South Asian community in Aotearoa New Zealand being the smallest out of the four case studies of this article, it actually had several regional associations as well as a central coordinating one.

There were also variations between the South Asian communities in Australia, Canada, Aotearoa New Zealand, and South Africa in terms of what part of South Asia they had come from. The South Asian community in Canada was predominantly from the Punjab, and mostly Sikh, during the period surveyed by this article. In Aotearoa New Zealand the South Asian community came from Gujarat mainly, but also from the Punjab. This is not surprising as these two parts of South Asia for various reasons saw large numbers of South Asians move to other parts of the world. ${ }^{86}$ The South Asian communities in South Africa and Australia were more diverse. Although there were very few, if any, Punjabi migrants in South Africa, there were notable numbers in Australia, including Sikhs. The South Asian community in South Africa was mostly divided between those who had come over as indentured

${ }^{86}$ Leckie, "South Asians," 137. 
workers, mainly from South India, and merchants who came via independent means from western India and Gujarat specifically.

As this article has shown the South Asian communities in all four countries studied in this article initially emphasised their status as British subjects, especially when they were trying to combat discrimination they faced. However, this identity began to shift in South Africa in the 1930s. This was mainly due to the fact that South Asian's status as British subjects there had done little to help counter the growing restrictions placed by white South Africans on their lives. Also you had second generation South Asian South Africans, who had very little or no attachment to their parents' British Indian subject identity.

All four countries saw the growth of a pan-South Asian identity develop amongst the South Asian communities in them. This was primarily due to the overt discrimination and hostility experienced by South Asians of all ethnicities, cultures, and faiths from white people in their respective countries (who were the majority population in three of the four countries of this study). This collective experience of discrimination broke down barriers that were still quite fairly entrenched in South Asia. However, this is not to suggest that the South Asian communities in Australia, Canada, Aotearoa New Zealand, and South Africa were monolithic blocs. As mentioned above they often came from quite disparate parts of South Asia, and quite often spoke different languages, and even practiced different faiths. So, they had a sense of their own communities' interests. But they were willing to put aside any potential differences for the greater good, which was combatting discrimination and prejudice that they all faced in their new homes due to their ethnicity. 
This article has surveyed the South Asian communities in Australia, Canada, Aotearoa New Zealand, and South Africa, between the 1900s and 1940s. Specifically it has explored in each case study, whether South Asian migrants used the rhetoric of being British subjects. In addition, the article also considered whether the experience of living in predominantly majority white countries at the time encouraged South Asian communities, of different ethnicities, cultures, and faiths, to create a pan-South Asian identity. It has shown that South Asian migrants in Australia, Canada, Aotearoa New Zealand, and South Africa did indeed use the rhetoric of their status as British subjects. However, this began to shift in South Africa from the 1930s onwards. This was primarily because this status had not done very much to protect South Asians in South Africa against increasing restrictions upon their lives by the white dominated Union governments and even the establishment of the beginnings of segregation. The fact that the South Asian community there was also the longest-established, meant South African born South Asians also did not have an affinity with their parents' British Indian subject status. Living in predominantly white majority countries did also generally lead to the creation of a pan-South Asian identity amongst the South Asian communities in Australia, Canada, Aotearoa New Zealand, and South Africa. Common experiences of discrimination and prejudice encouraged disparate groups to put aside their differences and work together to combat these. This was quite a contrast to the situation in South Asia at the time, especially increasingly in terms of faith.

\section{Bibliography:}

\section{Primary Sources}

National Archives of the UK (NAUK) 
Colonial Office (Hereafter CO) 886/4/1: 'Further correspondence of [1910 and 1911] relating to the Treatment of Asiatics in the Dominions.' (In continuation of Dominions no 10; continued by Dominions No.44)

CO 886/6/1: Further correspondence [1912-1913] relating to the Treatment of Asiatics in the Dominions. (In continuation of Dominions No.21; continued by Dominions No.55)'

CO 886/7/5: 'Further Correspondence [1916-1917] relating to the Treatment of Asiatics in the Dominions. (In continuation of Dominions No.55).'

CO 886/7/13: 'Further Correspondence [1916-1917] relating to the Treatment of Asiatics in the Dominions. (In continuation of Dominions No.55).'

CO 886/8/7: 'Further Correspondence [1918-1919] relating to the Treatment of Asiatics in the Dominions (In continuation of Dominions No.63; continued by Dominions No.74)

CO 886/9/1: 'Further Correspondence [1919 (Nos 1,2 and 50), 1920 and 1921] relating to the Treatment of Asiatics in the Dominions (In continuation of Dominions No.70; continued by Dominions No.85)'

Dominion Office (Hereafter DO) 35/600/1: Position of Indians in South Africa, 1939

DO 35/1122/26: Indians in the Union, 1943-1946

British Library (BL)

India Office Records (Hereafter IOR)/L/E/7/1260, File 650: Indians in Australia, 28 May 1920-3 Nov 1921

IOR/L/E/7/1183, File 88(iii): Indians in South Africa, 6 Oct 1921-4 Feb 1926 IOR/L/PARL/2/369: Imperial Conference, 1911 
IOR/L/PJ/5/462: Volume containing papers on status of

British Indians in colonies and dominions, 1897-1911

IOR/L/PJ/6/1062, File 509: Indians in the Dominions; discussion at the Imperial Conference, 1911

IOR/L/PO/1/10: Indians overseas, 23 Jul 1923-26 Jun 1934

\section{Secondary Sources}

Allen, Margaret. “'A fine type of Hindoo' meets 'The Australian type': British Indians in Australia and diverse masculinities." In Transnational Ties: Australian Lives in the World, edited by Desley Deacon, Penny Russell and Angela Woollacott, 41-56. Canberra: ANU E-Press, 2008.

Allen, Margaret. "I am a British subject': Indians in Australia claiming their rights, 1880-1940." History Australia 15, no. 3 (2018): 499-518.

\section{https://doi.org/10.1080/14490854.2018.1485505}

Bandyopadhyay, Sekhar. "Reinventing Indian Identity in Multicultural New Zealand." In Asia in the Making of New Zealand, edited by Henry Johnson \& Brian Moloughney, 125-146. Auckland: Auckland University Press, 2006.

Bandyopadhyay, Sekhar. "A History of Small Numbers: Indians in New Zealand, c. 1890s-1930s." New Zealand Journal of History 32, no. 2 (2009): 150168.

Banerjee, Sukanya. Becoming Imperial Citizens: Indians in the Late-Victorian Empire. Durham, NC: Duke University Press, 2010.

Bhana, Surendra. Gandhi's Legacy: The Natal Indian Congress, 1894-1994. Pietermaritzburg: University of Natal Press, 1997. 
Desai, A. and Vahed, G. The South African Gandhi: Stretcher-Bearer of Empire. Stanford, CA: Stanford University Press, 2015.

Huttenback, Robert A. Gandhi in South Africa: British Imperialism and the Indian Question, 1860-1914. Ithaca, NY: Cornell University Press, 1971.

Huttenback, Robert A. Racism and Empire: White Settlers and Colored Immigrants in the British Self-Governing Colonies, 1830-1910. Ithaca, NY: Cornell University Press, 1976.

Johnston, Hugh J. M. The Voyage of the Komagata Maru: The Sikh Challenge to Canada's Colour Bar. Vancouver: UBC Press, 2014.

Lal, Brij V. , Peter Reeves, and Rajesh Rai (Editors), The Encyclopedia of the Indian Diaspora. Singapore: National University of Singapore, 2006.

Leckie, Jacqueline. "From Race Aliens to an Ethnic Group - Indians in New Zealand." In Ethnicity and Nation Building in the Pacific, edited by M. C. Howard, 169-197. Tokyo, 1990.

Leckie, Jacqueline. "South Asians: Old and New Migrations." In Immigration and National Identity in New Zealand: One People, Two Peoples, Many Peoples?, edited by Stuart William Greif, 133-160. Palmerston North: Dunsmore Press, 1995.

Leckie, Jacqueline. Indian Settlers: The Story of a New Zealand South Asian Community. Dunedin: Otago University Press, 2007.

Maclean, Kama. "Examinations, access, and inequity within the empire:

Britain, Australia and India, 1890-1910.” Postcolonial Studies 18, no. 2 (2015): 115132. https://doi.org/10.1080/13688790.2015.1044483

Maclean, Kama. British India, White Australia. Sydney, NSW: UNSW Press, 2020. 
McLeod, Hew. Punjabis in New Zealand: A History of Punjabi Migration, 18901940. Amritsar: Guru Nanak Dev University, 1986.

Ramnath, Maia. Haj to Utopia: How the Ghadar Movement Charted Global Radicalism and Attempted to Overthrow the British Empire. Berkeley, CA: University of California Press, 2011.

Spector-Marks, Irina. “The Indians' Own Magna Carta': Britishness and imperial citizenship in diasporic print culture, 1900-1914." Journal of Colonialism and Colonial History 16, no. 3 (2015): 1-14.

Smith, Andrew and Mann, Jatinder. "Civic Nationalism, Imperial Identities, and Punjabi Migration: Sundar Singh's Political Activism in the Dominion of Canada." South Asia: Journal of South Asian Studies, vol. 39, issue 2 (June 2016): 305-328. https://doi.org/10.1080/00856401.2016.1155688

Tiwari, Kapil N. "The Indian Community in New Zealand: A Historical Survey." In Indians in New Zealand: Studies in a sub culture, edited by Kapil N. Tiwari, 1-84. Wellington: Price Milburn, 1980.

Westrip, Joyce and Holroyde, Peggy. Colonial Cousins: A Surprising History of Connections Between India and Australia. Adelaide, SA: Wakefield Press, 2010. 